\title{
THE ABSENCE OF ANTAGONISM BY NALOXONE DURING HALOTHANE/NITROUS OXIDE ANAESTHESIA IN MAN
}

\author{
B.A. Macleod, F.C. Ping and L.C. Jenkins
}

\begin{abstract}
Sixteen patients were studied to determine if naloxone could be shown to affect general anaesthesia with halothane and oxygen or nitrous oxide and oxygen with halothane. Changes in blood pressure, pulse rate, elect roencephalogram and evidence of physical response wcrc observed. The end-tidal halothane and carbon dioxide were controlled. The temperature and blood gases were held constant, as was the degree of neuromuscular blockade. Natoxone $1.2 \mathrm{mg}$ was administered during general anaesthesia with either halothane in oxygen or halothane with nitrous oxide to 16 patients who were premedicated without a narcotic. No significant responses were recorded.
\end{abstract}

The discovery of endogenous opiate-like substances (enkephalins) and specific opiate receptors in the brain ${ }^{1.4}$ has led to interesting speculation concerning their role in the production of analgesia." Naloxone, a specific narcotic antagonist, has been shown to enhance clinical pains as well as to decrease analgesia associated with acunpuncture and electrical stimulation of the periaqueductal grey areas in the brain..$^{6.7}$ In mice analgesia produced by nitrous oxide has been decreased by naloxone, and its administration in the rat during general anaesthesia with halothane, cyclopropane and enflurane resulted in increased somatic response to painful stimulus. ${ }^{8,9}$

In view of these findings it was decided to investigate the effect of naloxone on patients anaesthetized with halothane, and with halothane and nitrous oxide mixture.

\section{METHOD}

Sixteen female patients with ages ranging from 24 to 57 years were studied. All were A.S.A. Class I, scheduled for abdominal hysterectomy. Informed consent was obtained preoperatively. None were in pain preoperatively nor were they receiving preoperative analgesia.

The first eight patients were given halothaneoxygen anaesthesia, the next eight patients received halothane, oxygen and 60 per cent nitrous oxide.

B.A. MacLeod, M.D., F.R.C.P.(C), F.C. Ping, M.B., B.Ch., B.A.O., L.C. Jenkins, M.D., C.M., F.R.C.P.(C). Department of Anaesthesia, Vancouver General Hospital.

Canad. Anaesth. Soc. J., vol. 27, no. 1. January 1980
Premedication consisted of pentobarbitone $200 \mathrm{mg}$ orally two hours before operation.

Before induction of anaesthesia an electroencephalogram was recorded from four quadrants on a Beckman Superacutrace. Monitoring was by means of a sphygmomamometer, electrocardioscope, oral temperature probe and a peripheral nerve stimulator over the ulnar nerve. End-tidal halothane and carbon dioxide concentrations were monitored continuously on a Beckman infrared analyzer.

Induction was with thiopentone $5 \mathrm{mg} \cdot \mathrm{kg}^{-1}$ and treacheal intubation was facilitated by succinylcholine $1 \mathrm{mg} \cdot \mathrm{kg}^{-1}$.

When the blood pressure, heart rate, end-tidal halothane and carbon dioxide concentrations had remained unchanged for 15 minutes and there was no response to surgical stimulus, a tenminute control period was started. The end-tidal halothane concentrations at which the study was done were those which obtunded response to surgical stimuli of each individual patient. During this time the end-tidal halothane and carbon dioxide were held constant. The blood pressure and heart rate were recorded every two minutes. The electroencephalogram was recorded and the ulnar nerve was stimulated by a two-second tetanic burst at maximum voltage setting. The temperature was noted and the absence of evidence of inadequate anaesthesia such as sweating or grimacing was noted.

At the end of this ten-minute control period naloxone $1.2 \mathrm{mg}$ was injected rapidly intravenously. Over the next ten minutes the end tidal halothane and carbon dioxide levels were monitored continuously and again held constant. 29

Temperature, electroencephalogram and re- 
TABLE I

Mean Blood Pressure and Pulse Rate Before and After Naloxone (Group DAta)

\begin{tabular}{|c|c|c|c|c|}
\hline & $\begin{array}{l}\text { Mean blood pressure } \\
\text { pre-naloxone }\end{array}$ & $\begin{array}{l}\text { Mean blood pressure } \\
\text { post-naloxone }\end{array}$ & $\begin{array}{l}\text { Mean pulse rate } \\
\text { pre-naloxone }\end{array}$ & $\begin{array}{l}\text { Mean pulse rate } \\
\text { post-naloxone }\end{array}$ \\
\hline Group I & \multirow{2}{*}{\multicolumn{2}{|c|}{ No significant change }} & 77 & 78 \\
\hline$\left(\mathrm{O}_{2}\right.$ /halothane $)$ & & & \multicolumn{2}{|c|}{ No significant change } \\
\hline Group II & 98 & 94 & & 81 \\
\hline$\left(\mathrm{O}_{2} / \mathrm{N}_{2} \mathrm{O} /\right.$ /halothane & \multicolumn{2}{|c|}{ No significant change } & \multicolumn{2}{|c|}{ No significant change } \\
\hline
\end{tabular}

sponse to nerve stimulation were again noted. Blood pressure and pulse rate were again checked every two minutes. The patient was observed for signs of light anaesthesia.

\section{RESULTS}

No patient receiving either halothane or halothane-nitrous oxide showed any evidence of a decreased anaesthetic level following naloxone.

Table I shows mean values for blood pressure and pulse rate before and after naloxone administration. These were arrived at by averaging the blood pressure and pulse rate over the 10-minute pre-naloxone control period and for 10 minutes after naloxone.

A paired $t$-test revealed no significant difference between the pre- and post-naloxone values.

An example of an electroencephalogram recorded before a surgical anaesthetic level was reached is shown in Figure 1. The shift to a higher frequency and lower voltage upon electrical stimulation of the ulnar nerve are consistent with light anaesthesia. ${ }^{10}$ This was not seen in any of the patients during the control or post-naloxone periods.

Figures 2 and 3 represent typical elcctroencephalogram tracings. Both tracings show spindling patterns unchanged by the administration of naloxone. None of the patients revealed a change in the electroencephalogram.

No lacrimation, eye movements, sweating, or grimacing were noted in either the control or post-naloxone periods.

The temperature, end-tidal halothane and end-tidal oxygen concentrations also remained constant for the control and post-naloxone periods.

\section{Discussion}

No evidence of changing depth in halothane, or halothane/nitrous oxide general anaesthesia was
EEG LIGHTENING

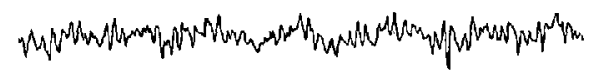

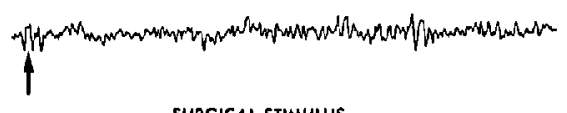

SURGICAL STIMUIUS

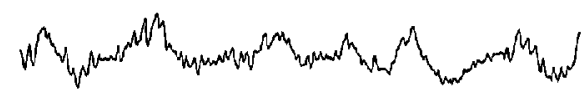

PRIOR TO SURGICAL STIMULUS

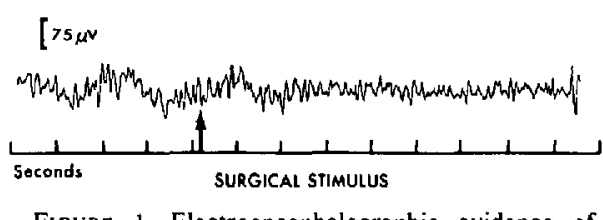

FIGURE 1 Electroencephalographic evidence of lighter anaesthesia.

found in our patients after they had received naloxone $1.2 \mathrm{mg}$ intravenously. The end-tidal concentration for each patient was held at the minimal level sufficient to obtund response to surgical stimulus. The use of a fixed MAC concentration of halothane (a population concept), is inappropriate to this study since at this concentration one-half of the patients would be responding to surgical stimulation.

This lack of effect contrasts with experiments in which an increased response to tail squeeze was reported in rats anaesthetized with halothane, cyclopropane and enflurane, as well as experiments in mice which indicated reversal of nitrous oxide analgesia when naloxone was given. ${ }^{8,9}$ In man, naloxone has been shown in some studies not to alter pain thresholds. "How. ever, in a recent study of dental patients, 
No. 6 K.R. O ${ }_{2}$ /HALOTHANE

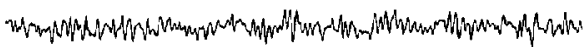

PRENALOXONE - BP $90 / 70$ PULSE 100

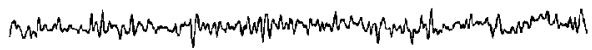

I MIN. POST NALOXONE BP $90 / 70$ PULSE 100

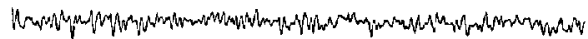

3 MINS POST NALOXONE BP $90 / 70$ PULSE 100

$[75 \mu \mathrm{v}$

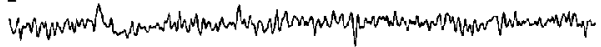

Soconds

5 MINS POST NALOXONE BP $90 / 70$ PULSE 100

Figure 2 Representative electroencephalogram before, during, and after naloxone during halothane anaesthesia.

No. 15 R.E. $\mathrm{O}_{2} / \mathrm{N}_{2} \mathrm{O} / \mathrm{HAL}$ OTHANE

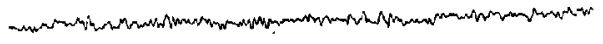

PRENALOXONE BP 110/80 PUL5E 90

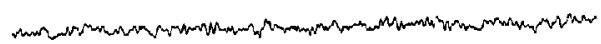

I MIN POST NALOXONE AP $110 / 80$ PULSE 90

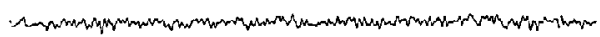

3 MINS POST NALOXONE BP $110 / 80$ PUISE 90

$\left[75 \mu^{2}\right.$

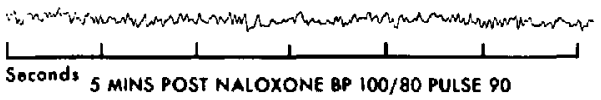

Figure 3 Representative electrocardiogram before, during, and after naloxone during halothane/nitrous oxide anaesthesia. naloxone has been shown to enhance clinical pain. ${ }^{5}$ Furthermore, naloxone has been shown to decrease acupuncture produced analgesia as well as analgesia produced by direct brain stimulation. ${ }^{6.7}$

Many possible reasons exist for the apparent variation in experimental results. First, the majority of the previous studies have measured changes occurring in the degree of analgesia, but the state of general anaesthesia is very different. The dosage used in animal experiments is much higher than that used in this study. It is difficult to extrapolate dosage from rat to man; however, corresponding doses of naloxone for reduction of analgesia induced by direct electrical stimulation of the brain are $1 \mathrm{mg} \cdot \mathrm{kg}^{-1}$ in the rat and a total of $0.2 \mathrm{mg}$ in man. ${ }^{7.12}$ Also, the respiratory cardiovascular and central nervous system depression induced by morphine in a dosage of $1.5 \mathrm{mg} \cdot \mathrm{kg}^{-1}$ in man, has been shown to be reversed by a dosage of naloxone of $5 \mu \mathrm{g} \cdot \mathrm{kg}^{-1} \cdot{ }^{13}$ Additionally, $0.8 \mathrm{mg}$ of naloxone has been shown to decrease acupuncture-induced analgesia in man. ${ }^{6}$ For these reasons the dose recommended as a maximum in the treatment of respiratory depression, or a total of $1.2 \mathrm{mg}$ was felt to be adequate to reveal any major role enkephalins might play in halothane and halothane-nitrous oxide anaesthesia.

The depth of anaesthesia chosen was surgical anaesthesia. An inverse relationship between mean arterial pressure and increasing MAC levels of both halothane and halothane-nitrous oxide anaesthesia has been demonstrated to occur during the first hour of anaesthesia, a period in which our measurements were made. ${ }^{14}$

The electroencephalogram patterns were consistent with light surgical anesthesia ${ }^{10}$ during all periods of control and naloxone administration.

Recent work in rats ${ }^{15}$ and dogs ${ }^{16}$ has shown no evidence of naloxone reversal of general anaesthesia. Our study in man also found no evidence of naloxone reversal during general anaesthesia with halothane, or halothane and nitrous oxide.

\section{REFERENCES}

I. Kuhar, M.J., Pert, C.B. \& Snyder. S.H. Regional distribution of opiate receptor binding in monkey and human brain. Nature 245: 447-450 (1973).

2. Goldstein, A. Opiate receptors. Life Sci. 14: 615-623 (1974).

3. Hughes, J., SMith, T.W., Kosterlitz, H.W., Fothergill, L.A., Morgan, B.A. \& Morris, H.R. Identification of two related pentopeptides 
from the brain with potent opiate agonist activity. Nature 258: 577-579(1975).

4. Pasternak, G.W., Goodman, R. \& Snyder, S.H. An endogenous morphine-like factor on mammalian brain. Life Sci. 16: 1765-1769 (1975).

5. Levine, J.D., Gordon, N.C., Jones. R.T. \& FIEI.D. H.L. The narcotic antagonist naloxone enhances clinical pain. Nature 272 (1978).

6. Mayer, D.J., Price, D.D. \& Rafu, A. Antagonism of acupuncture analgesia in man by the narcotic antagonist naloxone. Brain Res. 121: 368-373 (1977)

7. Akil. H., Mayer, D.J. \& Liebeskind, J.C. Antagonism of stimulation produced analgesia by naloxone, a narcotic antagonist. Science 191 : 961-962 (1976).

8. Berkowitz, B.A., Finck, A.D. \& NGai, S.H Nitrous oxide analgesia and its reversal by narcolic antagonists. Pharmacologist 18: 177 (1976).

9. Finck, A.D., NGal. S.H. \& BtRKOWITZ, B.A. Antagonism of general anaesthesia by naloxone in the rat. Anesth. 46: 221-245 (1977).

10. Faulconer, A. JR. \& Bickford. R.G. Electroencephalography in anesthesiology. Springfield, III., Thomas (1960).
11. El-Sobky, A., Dootrovsky, J.O. \& Wal.t, P.D. Lack of effect of naloxone on pain perception in humans. Nature 263: 783-784 (1976).

12. ADAMS. J.E. Naloxone reversal of analgesia produced by brain stimulations in the human. Pain 2: $161-166$ (1976).

13. Longnecker, D.E., Grazis. P.A. \& Eggers. G.W.N. Naloxone for antagonism of morphineinduced respiratory depression. Anesth. \& Analg. 52: 447-452 (1973).

14. Bahlman. S.H., Eger, E.E., Smith, N.T., Stevens, W.C., Shakespeare, T.F., Sawyer, D.C., Halsey, M.J. \& Cromwell, T.H. The cardiovascular effects of nitrous oxide halothane anaesthesia in man. Anaesthesiol. 35: 274285 (1971).

15. HarPer. M.H., Winter, P.M., Jolinson, B.H.\& EGER. E.I. Naloxone does not antagonize general anesthesia in the rat. Anesthesiol. 49:3-5 (1978).

16. PACE, N.L. \& WONG, K.C. Failure of naloxone and nathrexone to antagonize halothane anesthesia in the dog. Anesth. Analg. 58: 36-39 (1979).

\section{RÉSUMÉ}

L'objectif du travail était de déterminer l'effet du naloxone sur les niveaux d'anesthésie produits par les mélanges halothane-oxygène et protoxyde d'azote-halothane-oxygène. Seize patients volontaires ont été soumis à l'étude. On a observé les modifications de la pression artérielle, de la fréquence cardiaque, de l'électro-encéphalogramme ainsi que les manifestations physiques d'anesthésie légère, ceci après atteinte de conditions stables (halothane et $\mathrm{CO}_{2}$ de fin d'expiration, température, gaz artériels et degré de relâchment musculaire). Une dose de $1.2 \mathrm{mg}$ de naloxone était injectée à ce moment aux patients anesthésiés à l'halothaneoxygène et à ceux recevant le mélange protoxyde-oxygène. Aucune modification significative des paramètres étudiés n'a été observée. 